This item was submitted to Loughborough's Research Repository by the author.

Items in Figshare are protected by copyright, with all rights reserved, unless otherwise indicated.

\title{
Framing politics: The enduring appeal of the poster in British General Election campaigns
}

PLEASE CITE THE PUBLISHED VERSION

https://doi.org/10.1007/978-3-319-32498-2_17

PUBLISHER

(C) Springer

VERSION

AM (Accepted Manuscript)

\section{PUBLISHER STATEMENT}

This work is made available according to the conditions of the Creative Commons Attribution-NonCommercialNoDerivatives 4.0 International (CC BY-NC-ND 4.0) licence. Full details of this licence are available at: https://creativecommons.org/licenses/by-nc-nd/4.0/

\section{LICENCE}

CC BY-NC-ND 4.0

\section{REPOSITORY RECORD}

Burgess, Chris, and Dominic Wring. 2019. "Framing Politics: The Enduring Appeal of the Poster in British General Election Campaigns”. figshare. https://hdl.handle.net/2134/37563. 
Framing Politics: The Enduring Appeal of the Poster in British General Election Campaigns ChrisBurgess 1,* Email: cpburgess1983@gmail.com

Dominic Wring 2 Emaild.j.wring@lboro.ac.uk

1People's History MuseumSpinningfieldsM3 3ERManchesterUK

2Social SciencesLoughborough UniversityAshby RoadLE11 3TULoughboroughUK

Abstract

The poster has been the most durable form of political communication and has played a highprofile role in successive British General Election campaigns. The most well-known example of this was the work of the Saatchi and Saatchi advertising agency on behalf of the Conservatives during the run-up to the 1979 election. The firm's iconic imagery became an electoral issue when the incumbent Prime Minister questioned the ethics of the Saatchi campaign. However, as this chapter will demonstrate, this was far from being the first time that an advertisers' work for a political client had attracted controversy. Rather, the emergence of democracy in early twentieth-century Britain resulted in considerable experimentation with different forms of mass campaigning. Artists, designers and advertisers became increasingly involved in the electoral process through their production of innovative, stylistic imagery as part of concerted attempts to influence a burgeoning electorate. Posters played an integral role in these campaigns; moreover, they look set to continue doing so online as well as offline in a rapidly changing media environment. 1.

Introduction

The last century has witnessed significant advances in mass communication. These developments have meant that messages, notably those originating from political parties, are mediated in increasingly complex ways. This change has been facilitated by a huge expansion in print, broadcast and advertising forms over the course of the twentieth century. These burgeoning media have proven especially useful for politicians seeking to promote their case to the audience of millions newly enfranchised in the era of universal suffrage in Britain and also enabled them to target groups within what was perceived to be a decreasingly socially homogeneous electorate. The chosen focus for analysis in this chapter will be the General Election poster, arguably the most durable form of political advertising in British history. Unlike other types of persuasive communication, this format constitutes one of the least 'mediated', most direct kinds of appeal. As such, they offer 'the deliberateness of intention and the carefully constructed nature of the specific appeal' (Jowett and O'Donnell 1992, p. 117). Posters have also been an ever-present feature of elections fought since the nineteenth century and remain an important aspect of campaigning into the twenty-first century. Most existing work on posters traces their historical development through illustrated surveys of the form as a medium of social and economic as well as political communication (Barnicoat 1972; Gallo 1974; Hutchison 1968; Weill 1985). Within the latter category, broadly defined, there has been a perhaps understandable tendency to focus on times of war and revolution (Aulich and Sylvestrova 1999; Bonnell 1999; James 2009, p. 22; Rickards 1970). Cumulatively, such studies have provided invaluable contextual information on artists, genres and methods of production. By comparison, the limited research work that has been undertaken on the use of posters for electioneering is largely confined to specific parties and/or general election campaigns (Ball 2012; Gorman 1985, 1996; Lawrence 2009, 79-81; Thompson 2007). Though hugely useful, there is no comprehensive survey accounting for the continuities and changes in the production of election billboards as well as some appreciation of those responsible. This is perhaps surprising given that the poster is an important and at times controversial form of political communication that, unlike other media, lends itself to practical examination and analysis. This chapter intends to offer a sustained commentary on developments in Britain, an important site for experimentation and innovation in this domain. 
James Thompson has done the most to develop a coherent analysis of the efficacy of posters in his wide-ranging study of campaigning in the two decades either side of the turn of the twentieth century (Thompson 2007, pp. 177-197). Thompson demonstrates the centrality of pictorial propaganda to partisan electioneering during this period as well as the growing involvement of experts in producing a series of memorable images. The formation of linkages between parties and these publicity experts should further challenge received wisdom as to when the so-called 'professionalization' of campaigning began. There has been a tendency to focus on those elections post-Second World War and the interrelated growth of the television and marketing industries. The static medium of posters is, by comparison, perceived to be a quaint relic of what has been termed the 'premodern' phase of election campaigning (Norris 1997, pp. 197-211). But this arguably overlooks the importance of organic links forged between politicians and advertisers, in this case those responsible for designing what were state-of-the-art posters in the early twentieth century (Burgess 2014).

The chapter will identify the key creatives involved in this process and how their role has evolved to both reflect and inform mass democratic politics. Intriguingly, poster advertising has arguably enjoyed something of a renaissance with the fragmentation of traditional media audiences at the inception of the digital era. The subsequent proliferation of alternative messages, discourses and narratives combined with the apparent rise in voter disengagement has given urgency to the production of attractive poster imagery. Furthermore, such a conduit also finds an outlet via various online platforms that are available to be harnessed by campaigners seeking to maximize their reach to voters. As will be clarified in the following discussion examining its origins and development, the story of the political poster is far from over.

2.

Framing Politics

Politicians most obviously use posters as part of often more large-scale efforts designed to win over voters (Seidman 2008, pp. 125-162). In one of the earliest reports justifying the need for such advertising, a Conservative party strategist wrote in 1911 that the need to counteract the opposition had made them a necessity (Central Office 1911). However, these explanations are but some of the motivations as to why and how parties have mounted billboard campaigns over the course of the twentieth century and beyond. Why parties produced posters at the times they have depends entirely on context. As objects produced at a very specific time to speak to a specific group of people, posters have served many different purposes. Dumitrescu identifies various rationales for posters: informing voters; publicizing candidates; demonstrating presence to the electorate as well as opponents; mobilizing voters and activists; and convincing the undecided and/or firming up 'soft' supporters (Dumitrescu 2012; see also Trent and Friedenberg 2007, p. 358). Each of these has been, to a varying degree, a reason as to why British politicians have deployed poster campaigns in addition to more specific local factors, most notably the ban on televised, paid-for political advertising in the UK.

It remains illegal for any party or religious body to purchase airtime for a promotional purpose although periodically they are allocated free to air slots - the so-called Party Election Broadcasts (PEBs) - to present their views. This arrangement has been ratified by the 2003 Communications Act, which formed the most recent significant legislation to cover radio and television programming in Britain. The number of PEBs received is linked to a formula currently based on a party's previous vote share combined with the number of candidates being fielded. This format relies on voters watching at the time the broadcast is aired or accessing the content at a later stage. Consequently, this means posters offer politicians recurrent opportunities to reach the less suspecting voter through outdoor advertising or, as perhaps is becoming increasingly likely, viral online campaigns. The latter is not, however, 
without risks because activist critics can take issue and subvert messages with speed and impact.

Some critics of online posters have sought redress following publication of material that has offended. During the 2005 General Election, there was an interesting case when the then incumbent Labour party was criticized and referred to the industry regulatory body, the Advertising Standards Authority (ASA), for digitally publishing two images. Although these were supposedly only draft versions of potential advertisements, they were nonetheless widely circulated and discussed across a range of media because of their allegedly antiSemitic reference to the then Conservative leader Michael Howard's Jewish ancestry. Interestingly, by the time this referral was made, the ASA had by then redrawn its Code of Advertising Practice to rule out electoral politics, an arena that by its nature is potentially fraught, is complicated and raises issues to do with freedom of democratic expression. From the Authority's creation in 1962-1999, the regulator had had some limited oversight over posters when complaints were referred to it. But following a review by the ASA's Committee on Advertising Practice, the Code subsequently excluded electoral politics from its remit and has since advised the parties to regulate themselves (Committee on Advertising Practice 2014).

Despite the present ASA Code not extending to political advertising including posters, parties are still subject to general legal frameworks, most obviously those relating to libel as well as impositions on where material can be displayed including a ban on them appearing on trains and train stations. It should also be noted that while content may not be regulated, there are rules governing the costs of producing party publicity. Since 2001, maintenance of these restrictions on campaign expenditure has been a key function of the UK Electoral Commission formed that year. Thus, there are limits on what a party can spend both at the constituency and national level including on posters that can of course be deployed in specific seats or across the country (Fisher 2015). Advertising only qualifies as part of the more restrictive limits on local campaign expenditure if it is clearly geographically specific, most obviously through featuring the name of the individual candidate as well as that of the local rather than national agent. However, given such displays tend to appear in private dwellings, the minimal costs incurred are largely for printing rather than publicizing them.

The controversy relating to Labour's 2005 online campaign highlights how advances in design and technology have meant the nature of what constitutes a 'poster' has changed over time. Writing shortly before the outbreak of the Great War, designer John Hassall noted the three standard sizes then popularly in use: Double Crown (just over three-quarters of a metre by half), Double Demy (nearly a metre by just over half) and Double Royal (just over a metre by nearly two-thirds of one) with each available in 'broadside' (i.e. landscape) or 'upright' (portrait) versions (Hassall 1911, p. 133). Typically, the popular Double Crown format was displayed in multiples of four up to a total of 32 sheets in total, thereby creating an image that could be just over 3 by $4 \mathrm{~m}$. During the twentieth century, billboard capacity grew to up to 96 sheets, a gigantic display measuring slightly over 12 by $3 \mathrm{~m}$ (Decaux 2010). While many of the early, Edwardian era posters were in the written text style of advertisement (Lawrence 2009, 79; Thompson 2007, p. 108), pictorial displays were also important and became the norm thereafter as the costs of mass reproduction became increasingly affordable and artistic designs more experimental. As the century progressed, parties produced fewer designs and deployed them in ever larger formats. Photography also increasingly became the norm in place of the more traditional hand-executed designs.

During the latter part of the twentieth century, campaigners began to make a virtue of launching their new adverts at specially convened events to maximize the impact and pervasiveness of their imagery via conventional news media outlets. This method was commonly the only one through which the smaller parties, notably the third placed Liberal 
Democrats, were able to use posters as a means of communication in the absence of sufficient funds to mount the kind of outdoor advertising that would directly reach the electorate. In the 1992 General Election, for instance, the party's advertising agency designed and was able to successfully circulate its 'My Vote' message, a reference to the client's being on the side of the ordinary citizen, through a series of launches featuring billboard style imagery extolling this core theme. But it is not only challengers who adopt this strategy. In the 2010 General Election, Labour were only able to 'launch' a poster campaign courtesy of the television cameras gathered to see Prime Minister Gordon Brown and his leadership team unveil the various images. Lack of funds prevented the rolling out of conventional, countrywide billboard advertising of the kind mounted by the rival Conservatives, traditionally the wealthiest of the parties (Burgess 2011; Kavanagh and Cowley 2010, pp. 143-144). And of course, the now ubiquitous online social media platforms have afforded parties be they minor or major no end of opportunity to create what they intend and hope might become viral messages. Digital possibilities have transformed what is now classified as a 'poster': a conduit once considered outmoded has arguably enjoyed something of a renaissance. The proliferation of social media has added a further complexity to the debate over the efficacy or otherwise of political campaigning. The continuing presence of posters, on- or offline, indicates strategists still believe in them as a means of dissemination, particularly for key messages that might not otherwise be readily conveyed through conventional news media. In his exhaustive survey of the format, Seidman suggests such advertisements have influence although his was not an audience-oriented study (Seidman 2008). Among those who have considered the potential impact of advertising, there is a tendency to emphasize the traditional reinforcement and to not change model of influence established by the pioneering researchers of the mid-twentieth century onwards (Lazarsfeld et al. 1944, pp. 88-89 and p. 150). Interestingly, this 'minimal' effects perspective was something early strategists partially anticipated. Writing in 1932, for instance, a senior publicity official with Conservative Central Office suggested the brevity of political posters campaigns militated against them having an efficacy in their core mission to persuade voters (Cambray 1932, p. 177).

Similarly, in 1936 a Labour strategist recognized there was an important qualitative as well as quantitative dimension to the potency of this medium: '(A)dvertisement value is a subtle and almost immeasurable thing. It is certainly not intrinsic to its cost' (Wring 2005, 30). 3.

Poster Landscape

The early twentieth century witnessed a number of interrelated developments that cumulatively helped transform Britain into a mass democratic state. Central to this was the need for politicians to communicate to a growing electorate of millions. While the burgeoning newspaper provided an opportunity to disseminate information, parties sought other, more direct means of presenting their case and posters provided a highly useful format. 1906 had seen the widespread adoption of colourful and often caricatured imagery in the electoral propaganda issued during campaigns that year. Previously, the form had been dominated by written text-based advertisements that conveyed a great deal of information. It is highly debatable as to whether any but the most committed or informed citizens took much of an interest in what literally became wallpaper in various community settings.

By 1910, the outdoor political advertising format had gained recognition as part of a distinctive trend with the Pall Mall Gazette branding the first campaign of that year 'the poster election'. This was due to the vast scale, range and sheer number of posters that appeared and particularly in urban environments throughout the country (Pall Mall Gazette 1910). Conservative efforts were guided by the work of prominent commercial artist John Hassall. Furthermore, party activity of this kind was reinforced by material emanating from so-called 'Leagues' set-up and dedicated to campaign for assorted issues. Thus, prototype 
pressure groups such as the Budget League and Budget Protest League deployed posters as part of a sustained attempt to focus voter attention on a specific concern rather than the multiple subjects a conventional electoral politician would want to address.

The two General Elections of 1910 were immediate precursors to the era of near universal suffrage that followed in the wake of the Great War and the passing of the Representation of the Peoples' Act in 1918. This Act nearly trebled the size of the electorate and thereby created an obvious demand for mass political communication. For the first time, certain women were granted the vote before total female suffrage was confirmed a decade later. During this time, there were distinct changes in posters with more gendered imagery and especially artistic representations of women featuring prominently in electoral publicity. Much of this material focused on depicting female voters as mothers or housewives and typically related home economic metaphors to matters of public finance.

As mass democracy brought greater distance between MP and voter, during the interwar years the major parties adapted to democracy and the opportunities presented by mass media and communication. Parties saw the unmediated poster as a way of making personal appeals directly to the voter. Several strategists sought professional counsel from marketers, and there was a growing sophistication in politicians' understanding of campaigning during this period. As Graham Wallas put it in his classic book Human Nature in Politics first published in 1908: 'advertising and party politics are becoming more and more closely assimilated in method' (Wallas 1948, p. 87). Consequently, there was a marked tendency towards simplifying the message in the hope of creating more coherent and memorable communication. This trend was further influenced by the recognition that voters might not be as interested or knowledgeable as some politicians believed. Writing in 1921, one electoral agent wrote: 'A vast number of the electorate have little inclination to reason out political questions for themselves' (Burgess 1921) (on this see Fig. 1).

Fig. 1

Torn In Two, 1910. Source and used with permission from the London School of Economics Library's collections 


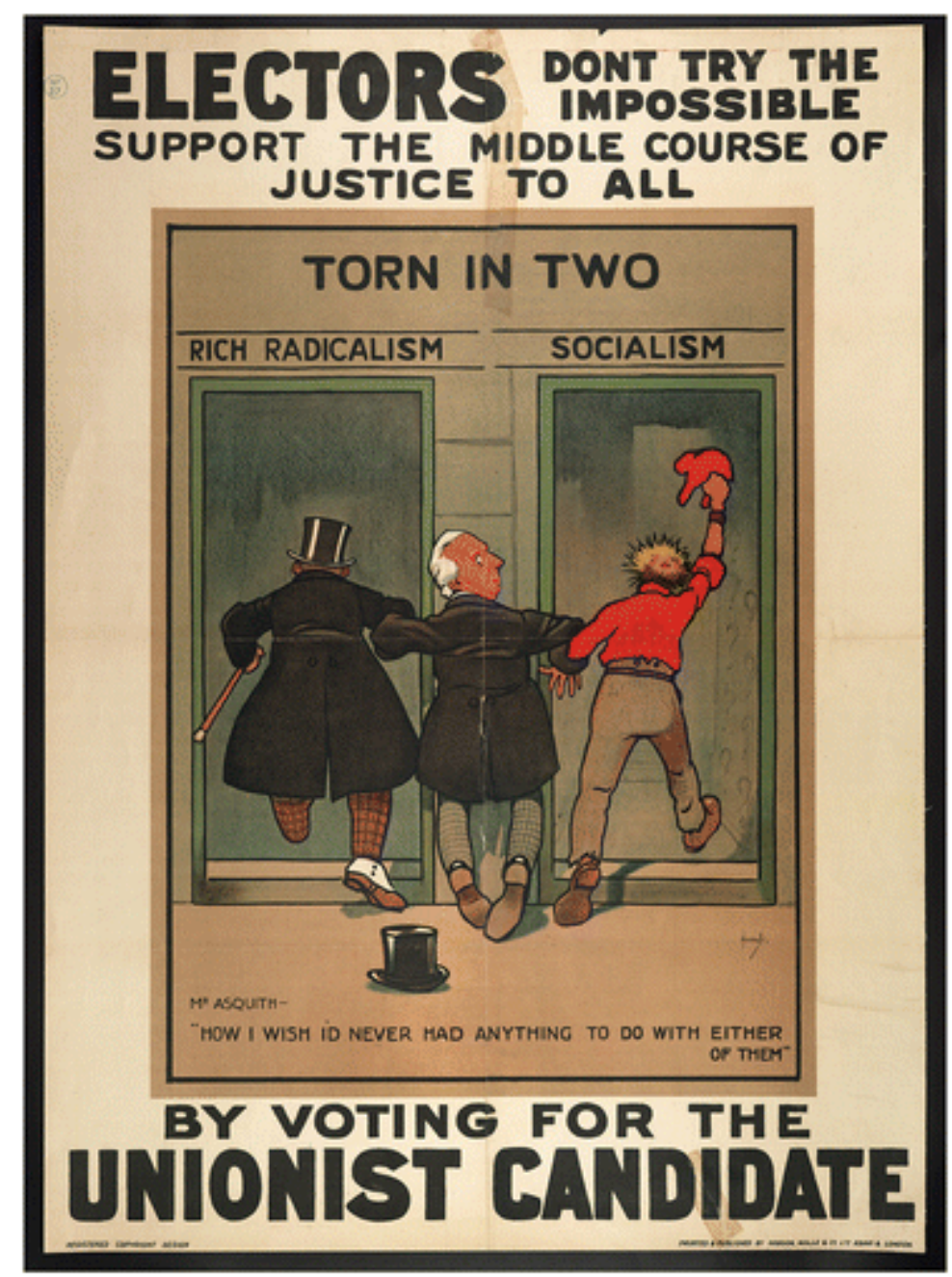

London School of Economics and Political Science 2007 Coll Misc 0519072

The respective party leaders and their images began to feature more prominently in posters such as 1929's 'Safety First' (Fig. 2) designed by the leading London agency SH Benson and which featured the face of their principal client, Conservative leader Stanley Baldwin.

Benson's would soon gain fame and recognition for the iconic 'Guinness is Good For You' campaign and brought with them consideration experience of the burgeoning marketing field. Rather than start from the premise that voters ought to take an interest in politics, advertising executives from the agencies such as Benson's were guided by the commercial imperative which assumed the public was largely indifferent and needed to be cultivated with care lest the message be ignored. Hence, the resulting Conservative campaign was simplified into the core proposition 'Safety First' along with an image of Prime Minister Stanley Baldwin as 'The Man You Can Trust!'.

Fig. 2

Safety First, 1929. Source and used with permission from Gettyimages 


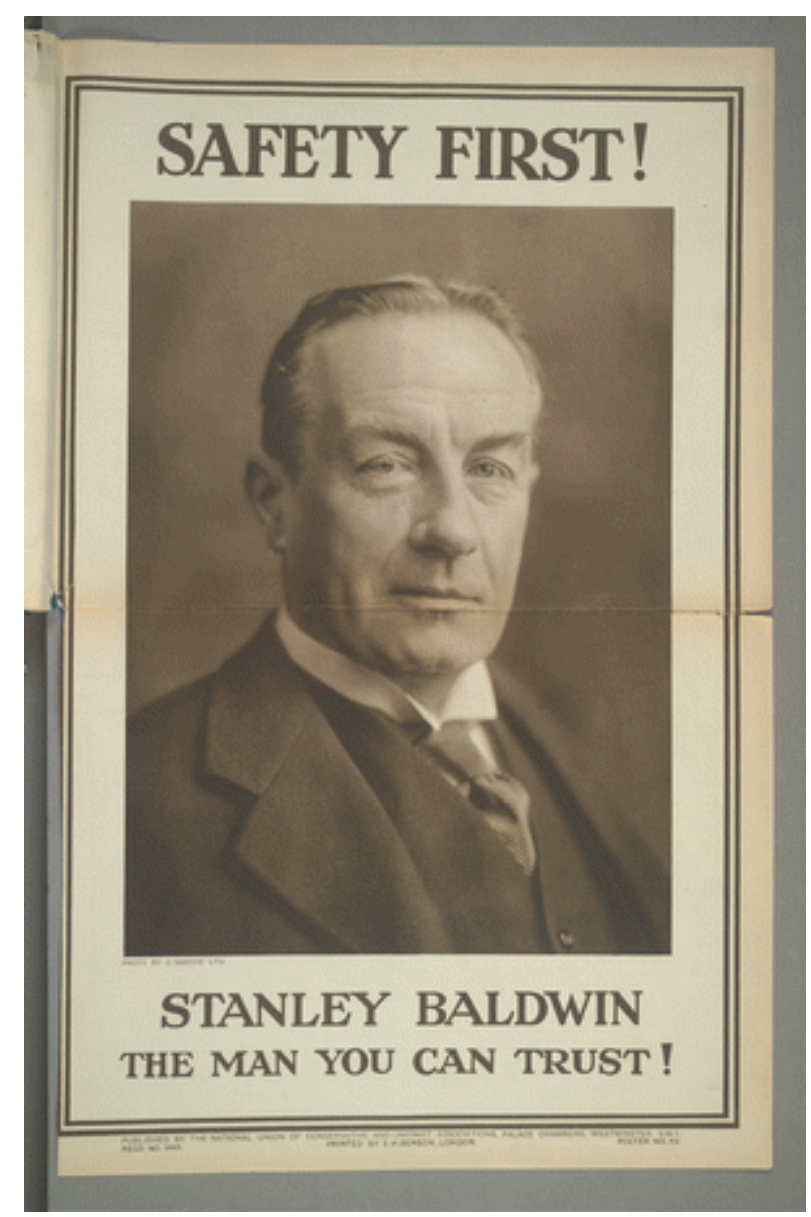

In some of their most memorable political imagery, Benson posters depicted various personalities representative of the kinds of voters to which the Conservatives wished to appeal. Much of this material appeared designed to emphasize the cohesiveness of society and featured women as well as men, the latter consciously chosen from different social strata. Although the party lost the subsequent election, there was sufficient support for retaining Benson's, and the agency's contract was renewed for the two further prewar contests. Significantly, the firm's extensive efforts on behalf of the Conservatives contributed to making 1935 one of the most expensive British General Elections of all time (PintoDuschinsky 1981, pp. 93-94). The party was by now the dominant force in the National government and also provided much of the funding that enabled the related National Publicity Bureau to create and sustain a formidable array of poster work.

Although Labour used posters from its inception as a political party, it did so in a way distinct from its Conservative rivals. Local branches adopted the format because it was a relatively inexpensive form of publicity. Furthermore, artists who were sympathetic to the party were able to create some extraordinary promotional imagery, an early example being the classic poster, 'Hope for Labour', produced for the 1906 election. During the 1910 elections, the party commissioned Gerald Spencer Pryse to create memorable images such as like 'Forward the day is breaking' (Fig. 3) and the anti-House of Lords' 'Labour Clears the Way'. More followed including the striking 1923 picture 'Greet the Dawn: Give Labour Its Chance' (PictureFig. 4) (Gorman 1985, p. 166). According to one contemporaneous account in the campaigners' monthly journal, the party needed to ensure that every poster needed to be 'an electoral howitzer' (Wring 2005, p. 33). Significantly, Labour did not, however, contract an agency on grounds of cost but also due to a suspicion among many within the party of advertising as a manipulative instrument associated with capitalism.

Fig. 3 
Forward the Day is Breaking, 1910. Source and used with permission from the People's History Museum

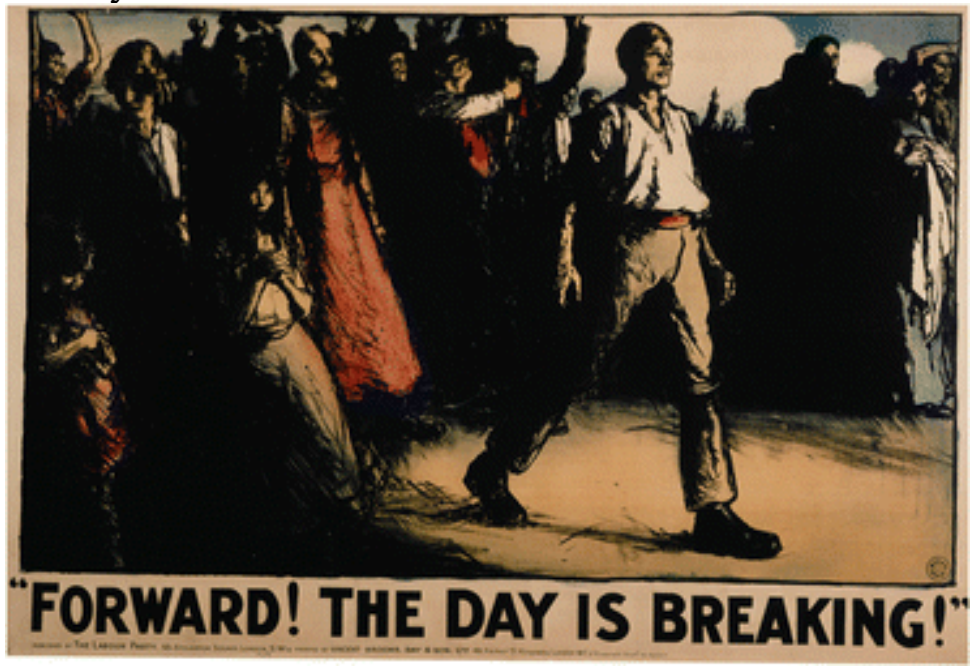

Professional guidance from marketers was not necessary to guarantee maximum publicity for the cause. Labour demonstrated this in 1935 when the party adopted the larger outdoor advertising format previously favoured by their principal opponents for a series of emotive designs including 'Election crosses or wooden crosses', a reference to the Conservatives' alleged warmongering. Another stark poster, 'Stop War', depicted an infant with a gas mask over their face and attracted adverse comments because of its highly emotive and controversial nature: critics claimed it was both in poor taste and defamatory. The poster was, however, seemingly vindicated a few years later when the wartime government began issuing masks to babies and children (Gorman 1985, pp. 168-9). But most publicity was not, however, so controversial given it mainly emulated the party's stated mission to transform society. Posters created for the 1945 General Election would showcase this intention (Fig. 4). Fig. 4

Greet The Dawn, 1923. Source and used with permission from the People's History Museum 


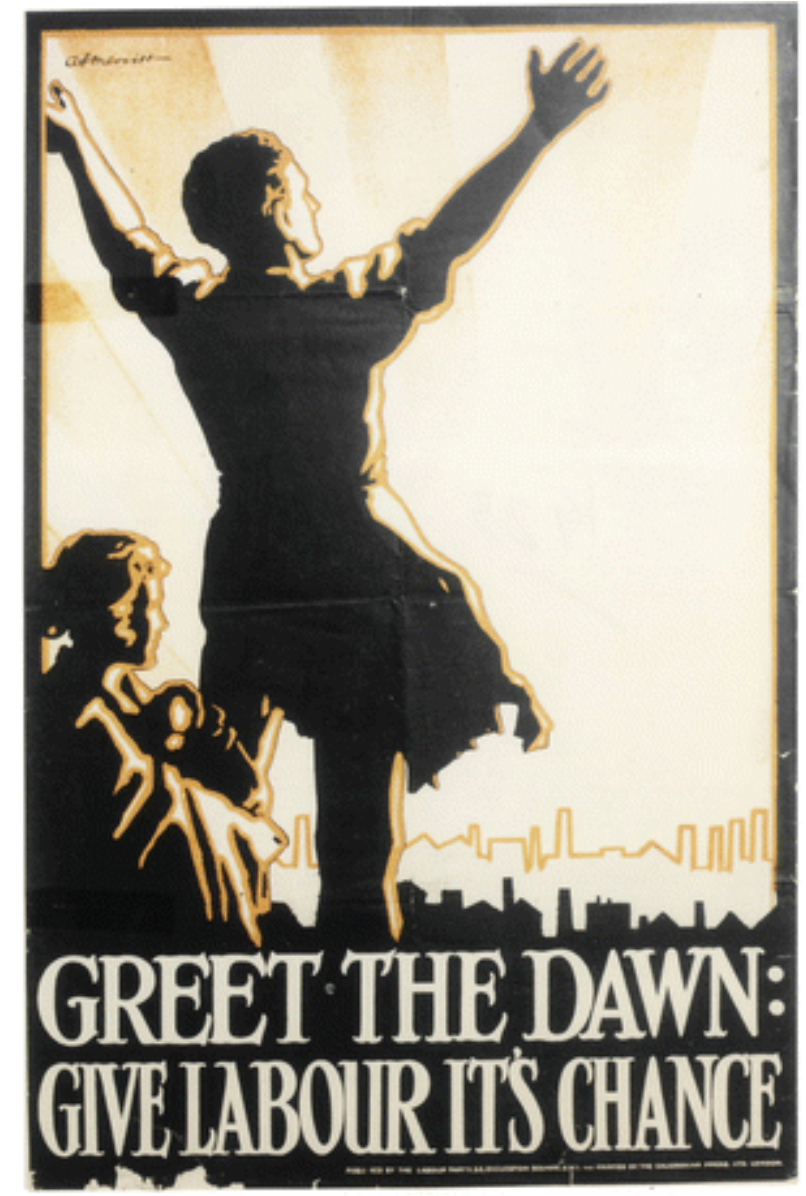

The 1945 campaign was unusual by twentieth century standards because it was comparatively unmediated and fought during the closing months of the Second World War. End of conflict meant a rationing of newsprint, and so other more direct forms of political communication such as posters were critical to party efforts to get their message across to voters. Labour publicity captured the mood of hope after the years of austerity followed by warfare (Beers, 2010). Among the various classic messages were the striking series of 'Vote for Them' images designed for the party by influential cartoonist Philip Zec. Zec's posters-each featuring a particular character representative of a different age or class demographicimplored citizens including the many returning service personnel to be mindful of casting their ballots in the interests of others as well as their own (Fig. 5). Labour's ambitious plans to recreate a more egalitarian Britain were alluded to in John Armstrong's iconic slogan 'And Now-Win the Peace' above a 'V' graphic symbolizing the Allied victory (Gorman 1996) and appropriating Churchill's famous hand gesture for their own use (Fig. 6).

Fig. 5

Labour For Homes, 1945. Source and used with permission from the People's History Museum 
SHE CAN'T MAKE A HOME TILL SHE GETS ONE... SO IT'S -

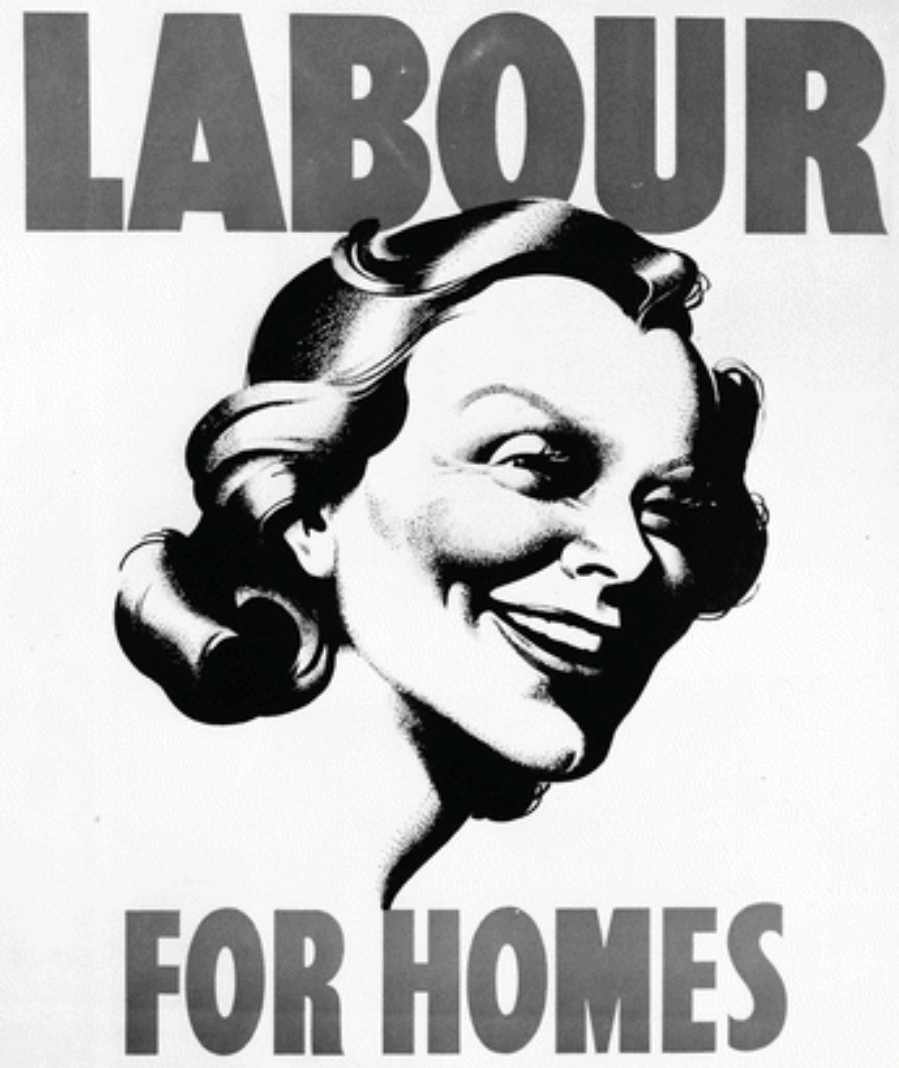

A VOTE FOR LABOUR MEAMS A FULL MATIONAL EFFORT FOR HOUSING

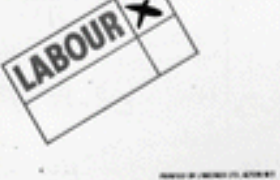

Fig. 6

And Now Win the Peace, 1945. Source and used with permission from the People's History Museum 


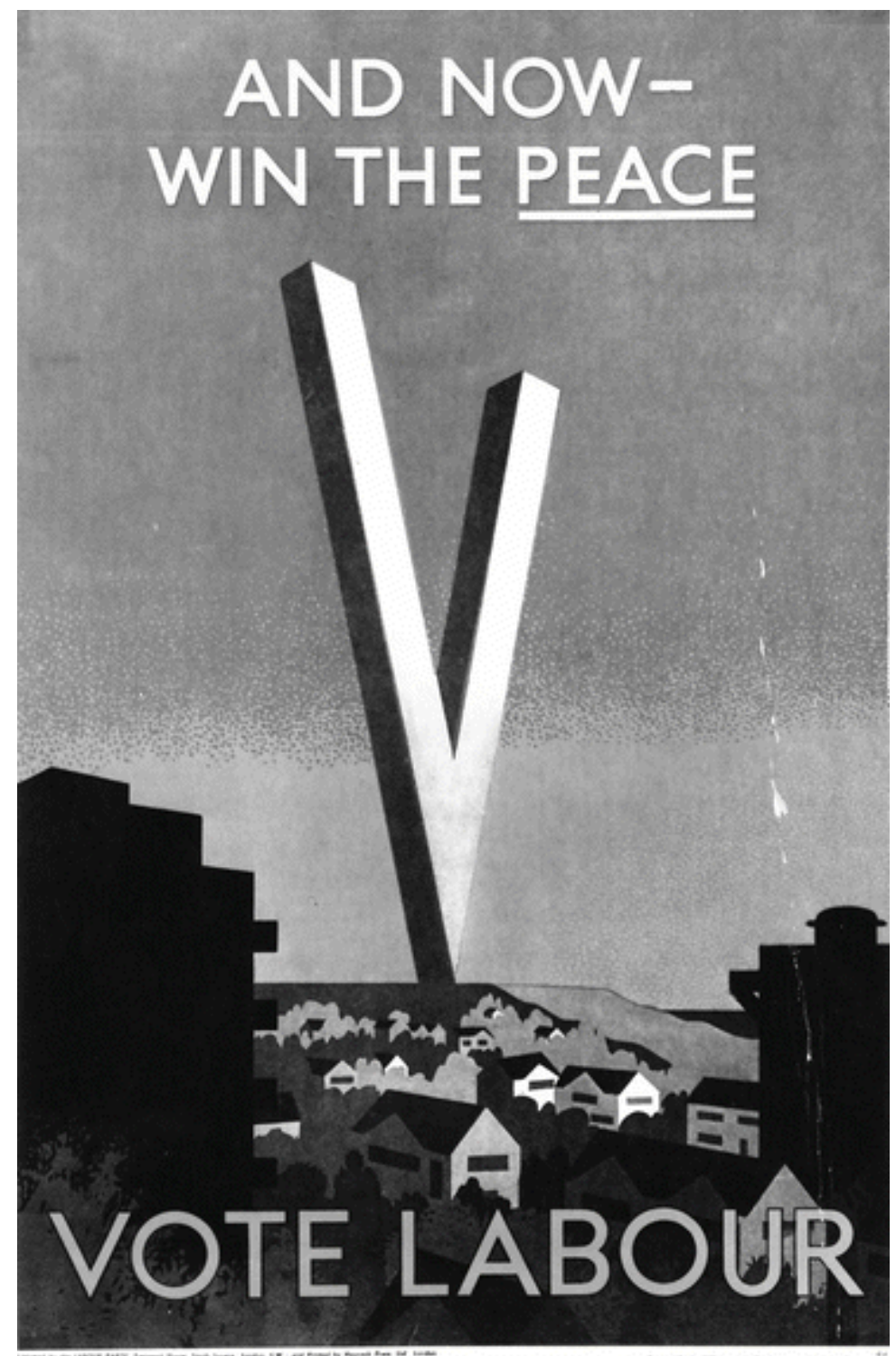

4.

Enduring Medium

Posters continued to play a significant role in election campaigns during the decades following the economic recovery that began in the 1950s. This was an important period in the expansion of the advertising industry given the marked increase in consumer activity and the arrival of commercially funded television. Mass audience small screen viewership provided marketers with the perfect access to the household and by extension the popular consciousness. But this did not signal an end to outdoor advertising, particularly of an electoral nature, because parties were banned from buying airtime slots of the kind purchased by candidates in the United States. This restriction remains in place to the present day, but British politicians are able to promote themselves through an allocation of the so-called Party Election Broadcasts. First aired on radio in 1924 and televised in 1951, PEBs are required to be a few minutes in length and are also covered by regulations governing all broadcast outputs. By contrast, posters have not been subjected to the same degree of legally sanctioned scrutiny. Arguably more importantly, the format enabled parties to continue to disseminate pithier, more provocative messages to the large swathes of the electorate who would not ordinarily consume political content. These 'low involvement' voters could therefore still be reached through eye-catching posters. 
Following their historic defeat in 1945, the Conservatives regrouped and hired Colman Prentis Varley (CPV) to help revive their profile. CPV was one of the leading London agencies whose growth represented the growing prowess of the British advertising agency, and their relationship with their political client proved to be both enduring and mutually beneficial. After their appointment in 1948, the firm contributed to the Conservative recovery in the 1950 General Election and to the three consecutive victories that followed during that decade (Cockett, 1994). Among the firm's work for the party, one image from the 1959 campaign has proved particularly enduring: 'Life's better with the Conservatives - don't let Labour ruin it'. It was a good example heralding how posters were becoming increasingly reliant on photography rather conventional artwork. The accompanying slogan formed a strapline to an idyllic scene of domestic family life and emulated a comment - 'You've never had it so good' - widely attributed to but never actually spoken by the then party leader and Prime Minister Harold Macmillan. It was a reference to the then ongoing consumer boom as well as an obvious aspirational appeal to individuals to act in their and their families' economic self-interest.

The 1959 campaign was significant because it was supposedly Britain's first real 'television election'. But CPV's influential work more than amply demonstrated that there was still a role for static visual campaign imagery. The firm's ability to distil and convey the Conservative message in poster form revived opposition criticism of their supposedly 'slick' methods as prominent Labour politician Richard Crossman attacked the agency for having sold Macmillan 'as though he were a detergent' (Butler and Rose 1960, 20). Crossman's party remained wedded to more ad hoc arrangements for producing its advertisements, preferring to use sympathetic designers like FHK Henrion. Henrion was involved in producingdevising a series of posters such as 'Labour will never forget the old folk' that was markedly less stylized than their Conservative counterparts (Butler and Rose 1960, p. 27 and p. 48). The subsequent defeat, the third in a row, led to pointed criticism of the party's approach to publicity more generally with one prominent critique complaining about a failure to use personal imagery more effectively: 'One photograph of Mr Macmillan pruning his rose garden with a pair of non-sequiters is worth half a dozen solid speeches by Mr Gaitskell' (Rowland 1960).

When the then Labour leader Hugh Gaitskell died unexpectedly the year before the 1964 General Election, the party had already undergone a rethink over its communication and media strategies. His successor Harold Wilson was, if anything, more ambitious in reforming Labour's campaigns through bringing in a team of marketing experts and giving them unprecedented influence (Wring 2005). This challenged the pre-existing system where most major publicity decisions had been made by a subcommittee of the party's ruling National Executive. In doing so, Wilson was motivated by a belief that CPV's advertising including its prominent poster work had been integral to the Conservatives' success (Wilson 1986, p. 170). Consequently, Labour's advertising advisers were empowered to make critical decisions and thereby apply the latest professional techniques and thinking in pursuit of campaign objectives. This resulted in a highly simplified message 'Let's Go With Labour (Fig. 7) and We'll Get Things Done' adorning every major promotion including an extensive poster offensive (Fig. 7).

Fig. 7

Let's Go With Labour, 1964. Source and used with permission from the People's History Museum 


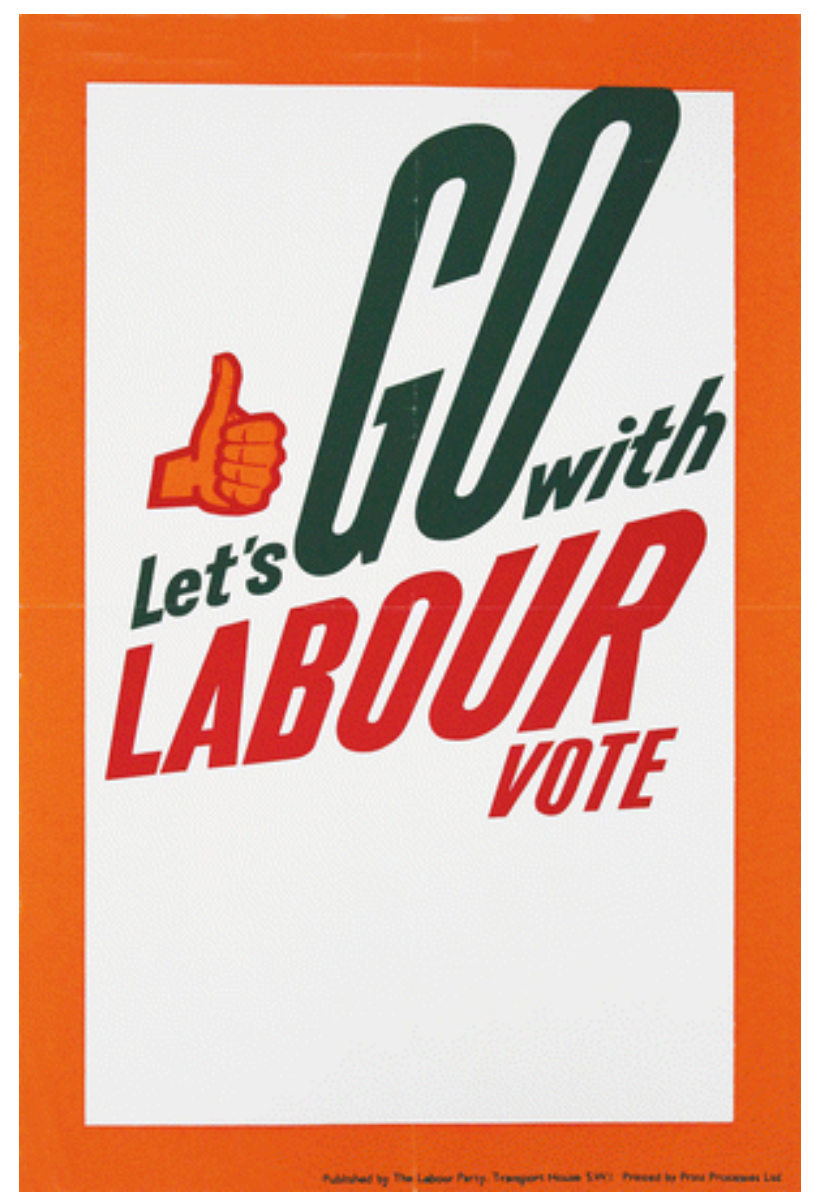

The 'Let's Go' team subsequently produced another successful campaign including posters with the common theme 'You Know Labour Government Works' for the 1966 General Election. The slogan was obviously based around the by now incumbent party's track record and was followed by a more emphatic victory. This achievement and Harold Wilson's patronage ensured that the marketing team continued to play an influential role. This was not without controversy, and Wilson's apparent reliance on his advertising advisers became a major issue during the 1970 General Election. The trigger for this was a party campaign based around a poster, 'Yesterday's Men' (Fig. 8), featuring waxwork miniatures of the Conservative leadership designed by the artist Alan Aldridge. Significantly, the imagery was attacked as being overly negative by Labour partisans as well as a range of other commentators.

Fig. 8

Yesterday's Men, 1970. Source and used with permission from the People's History Museum 


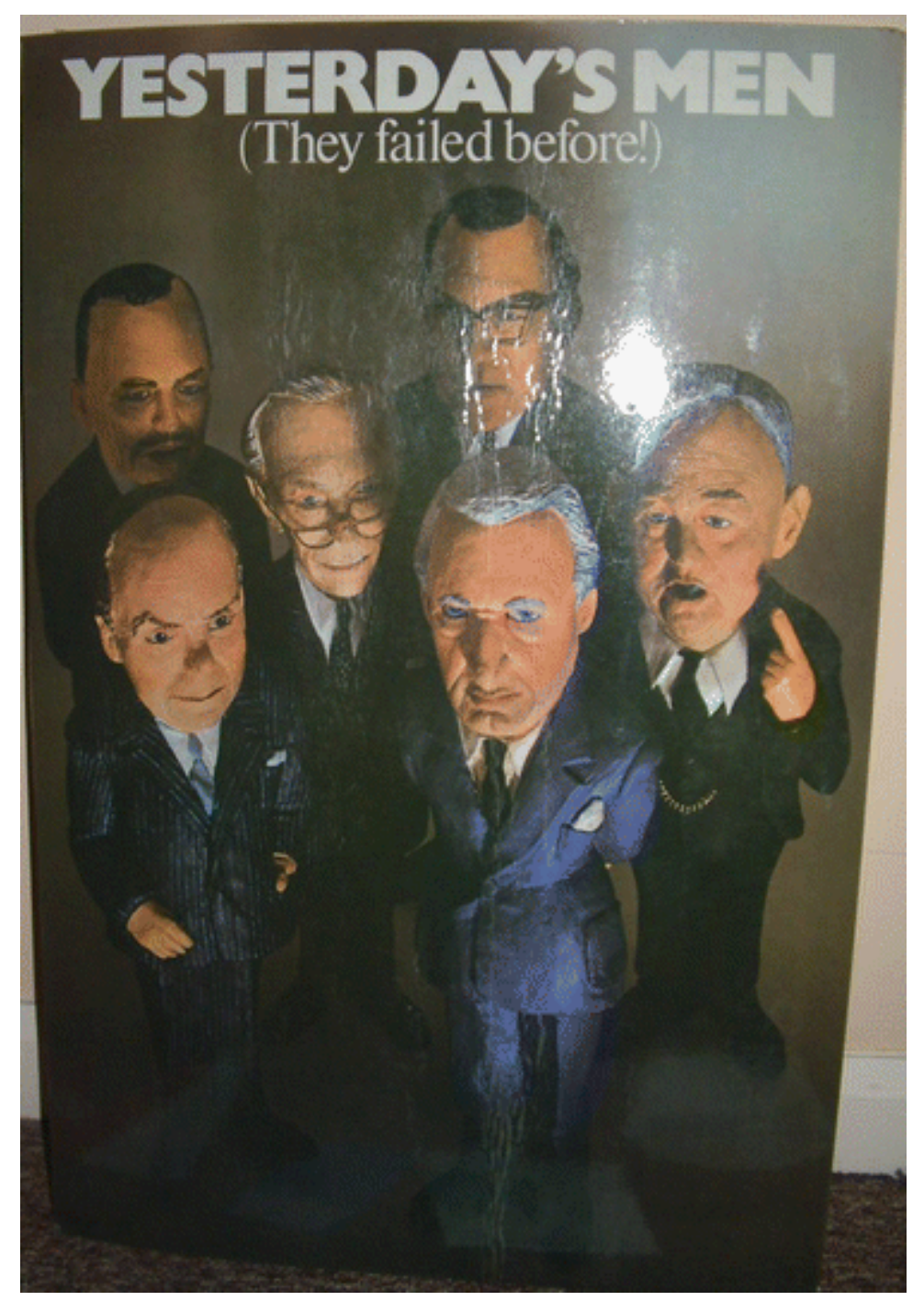

5.

Saatchi Effect

Few election posters stay in the collective memory let alone the popular consciousness long after the original time of publication. The most obvious exception is 'Labour Isn't Working', an advertisement highlighting the then mass unemployment problem that was created for the Conservatives during the run-up to their victory in the 1979 General Election. Since its first appearance, the image has become a motif for a campaign that heralded what became a momentous ideological shift following the installation of Margaret Thatcher as Prime Minister. The product of a close, seemingly symbiotic relationship between the party and advertising agency Saatchi and Saatchi, the poster was first unveiled in 1978 and subsequently came to symbolize the party's subsequent triumph the following year. For some leading Conservatives, the image also had a practical impact in helping to dissuade the then incumbent premier James Callaghan from calling an election 6 six months before he was forced to do so in May 1979, though substantive proof of this is hard to find. During the interim period, Labour endured the so-called torrid 'Winter of Discontent' that further eroded its poll ratings (Butler and Kavanagh 1980, p. 140).

Saatchi and Saatchi were understandably proud of their campaign for the Conservatives; indeed, much of the poster's myth was generated by the agency. The mutual relationship between client and agency would continue for some years. Their iconic political work became an important part of their identity, and Tim Bell, the Saatchi executive responsible for liaising with the Conservatives, argued the image "will probably go down in history as 
one of the most effective political posters ever produced' (Bell 1982, p. 16). This contention is nonetheless disputed. Psephologist Ivor Crewe suggested the assumptions behind Bell and others' belief are misplaced because 'only a small minority of the electorate noticed the Conservatives' posters more than those of Labour' during the 1979 General Election (Crewe 1981, 269-70). Linked to this point, Margaret Scammell has suggested the iconic image was one among many advertisements that appeared for only a couple of weeks during a protracted campaign and that its fame derives more from its subsequent notoriety rather than its supposed direct influence on the voting public (Scammell 1995).

Despite the questioning as to the electoral value of the Saatchi agency's work, there can be little doubt as to its enduring legacy. This was confirmed when leading advertising trade magazine Campaign voted 'Labour isn't working' (Fig. 9) its 'poster of the century' (Campbell 1999). Plaudits such as this have reinforced the claim by Martyn Walsh, one of the creative team originally responsible for the design, that it has become the 'benchmark' having 'influenced all political advertising since and (that) effectiveness is measured against it' (Horrie 2001). Most obviously the Conservatives believed in their agency and their approach by re-employing them for the successful re-election campaigns of 1983, 1987 and 1992. Somewhat intriguingly ideological opponents have also paid a backhanded compliment by recycling 'Labour's Isn't Working'. Within a year of the Conservative's 1979 victory, a critical newspaper cartoonist adapted the imagery to produce a feature mocking the then growing levels of unemployment with the caption 'So much for Tory election promises' (Caldwell 1980). Similarly, the later economic crisis of 2007-2008 led to anti-austerity campaigners appropriating the design in a banner emblazoned with the slogan into 'Capitalism Isn't Working' (SCAN 2012).

Fig. 9

Labour Isn't Working, 1978. Source and used with permission from Gettyimages 


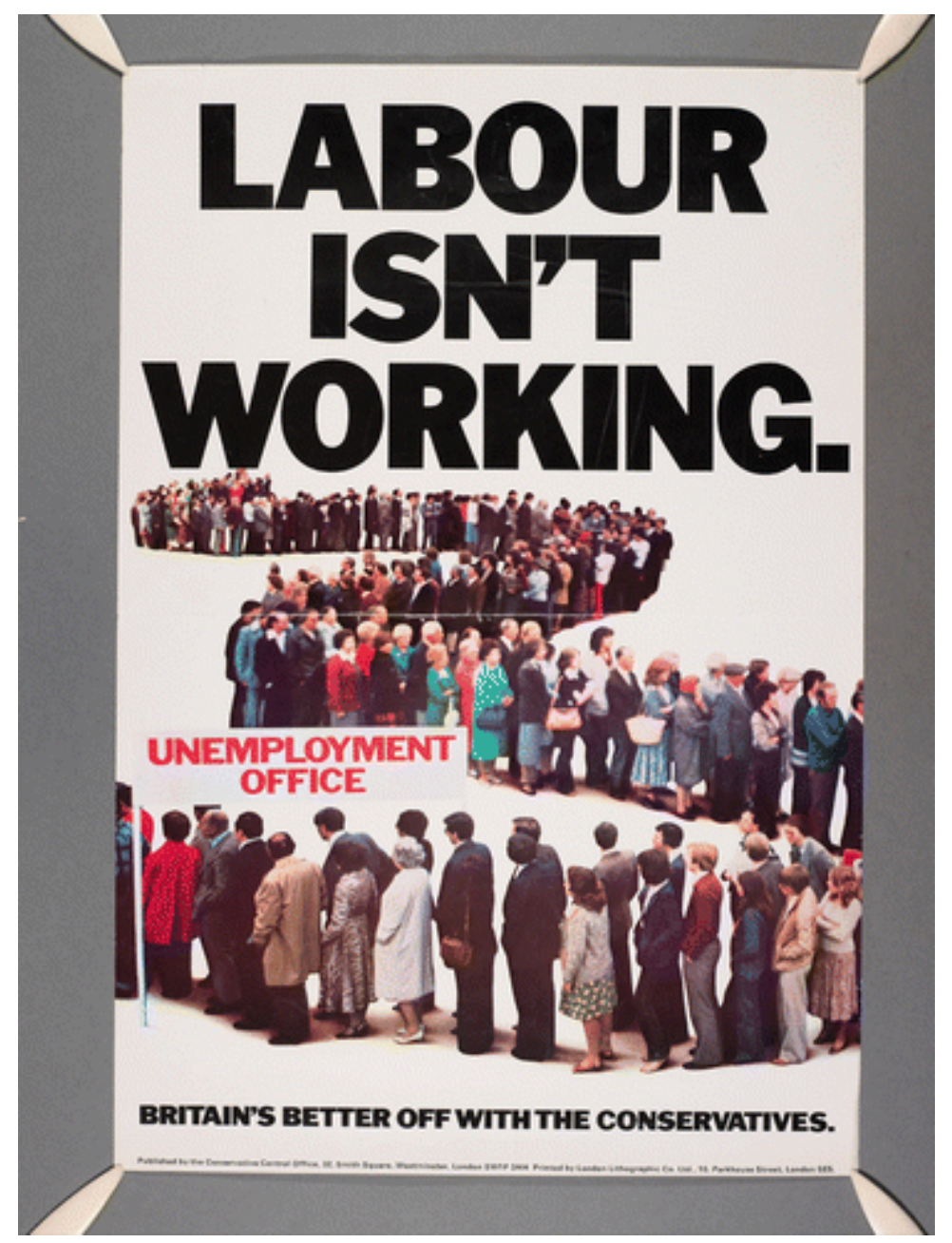

6.

Agency Work

The Saatchis' impact on politics was more than just about the aesthetics of electoral advertising. The close and enduring relationship between the firm and its client encouraged the Conservative's rivals to employ the services of an agency. Labour had hitherto relied on strategic help from individual designers and artists or informal teams of marketing experts in preparing its campaigns. For the first time in 1983, the party hired an agency, Johnny Wright and Partners, to devise all of its electoral advertising including its posters. But Wright and his colleagues were employed with little time to adequately prepare and nor did they command the resources to make the same kind of impact as their Saatchi rivals. Things rapidly changed following a further Labour defeat as the party embarked on an ambitious overhaul of both its organization and image. Central to this process was the Shadow Communications Agency (SCA), a voluntary network of advertising and PR professionals formed by Philip Gould to provide a headquarters' communications team led by Peter Mandelson with expert guidance (Wring 2005) (Fig. 10).

Fig. 10

The Country is Crying our for Change, 1987. Source and used with permission from the People's History Museum 


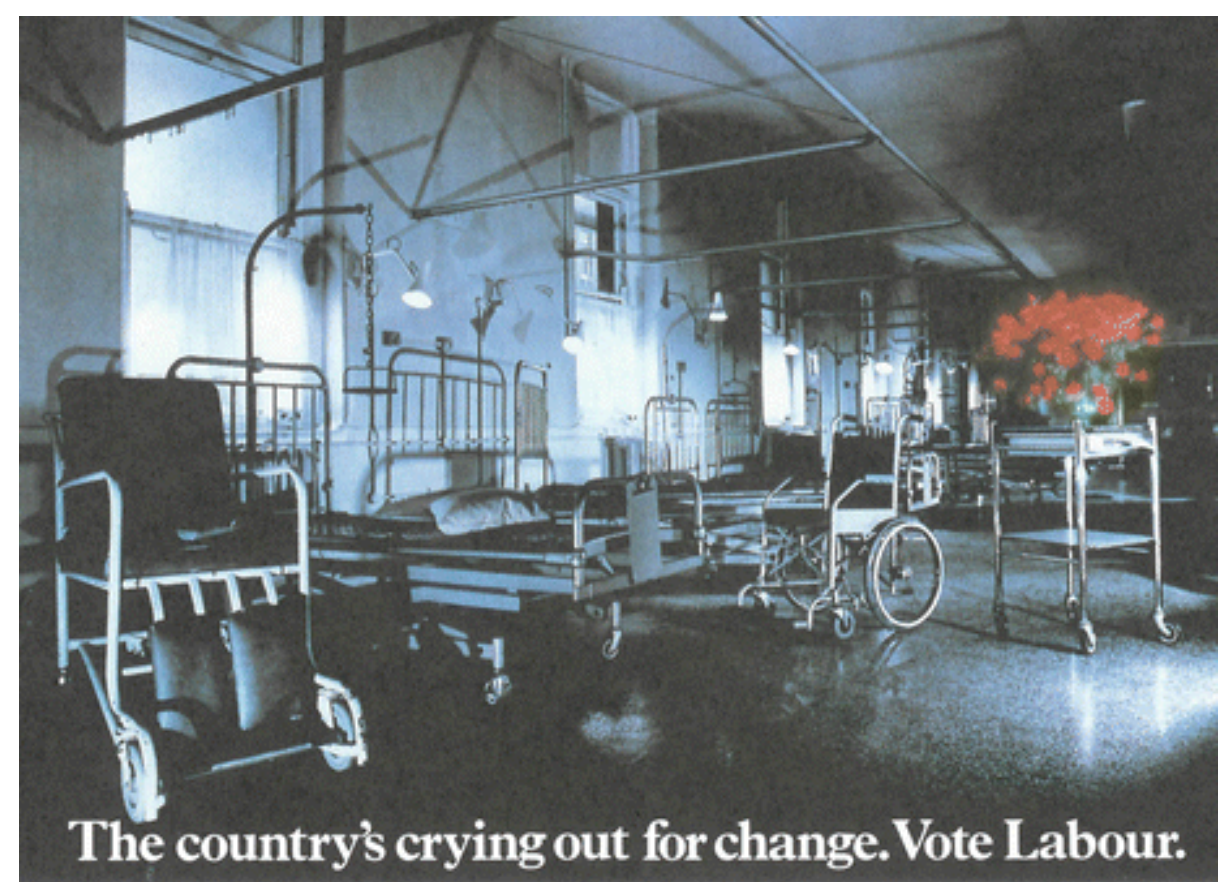

Several senior executives associated with the leading London agency BMP DDB Needham became central to the SCA arrangement and helped devise a series of campaigns culminating with the 1987 and 1992 General Elections. The former, in particular, featured several arresting posters including Labour's new branded red rose as well as attacks on the Conservative record including the government's running of the National Health Service (PictureFig. 10). Although this and the following campaign of 1992 resulted in further defeats, the BMP executives and their agency were formally appointed to work for the party prior to the 1997 General Election. Posters remained integral to the ensuing and highly selfconsciously stylized 'new' Labour rebranding, and leader Tony Blair's face adorned a series of outdoor advertisements including outlining one or other of his key campaign pledges. Blair also featured in Conservative attacks, notably the memorable and controversial 1996 'Demon Eyes' campaign (Fig. 11). This advert depicted the Labour leader's face with the upturned, red tinted eyes (of an unnamed actor) superimposed to create a sinister looking character. Initially created as a newspaper advert, this image gained greater notoriety when it was recycled in poster format.

Fig. 11

Demon Eyes, 1996. Source and used with permission from Gettyimages 


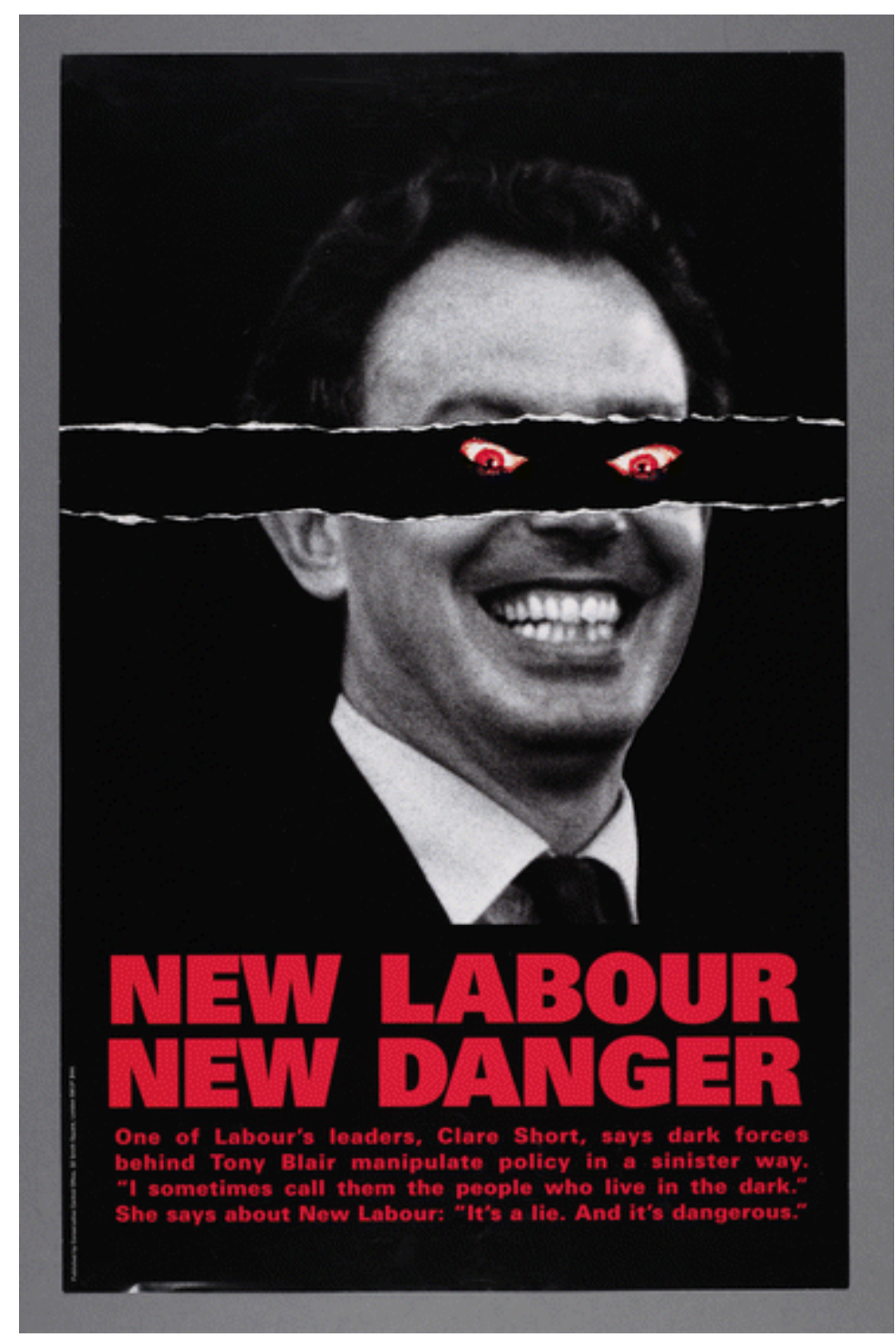

Tony Blair's character remained an issue in the two further General Elections he won as leader and Prime Minister in 2001 and 2005. Whereas opposition posters in the former focused on alleged broken promises, particularly the perceived failure to adequately fund public services, the latter campaign featured pointed criticisms of Blair's controversial decision to support the 2003 US-led invasion of Iraq. While the Conservatives' posters urged voters to 'Wipe the smile off his (Blair's) face', an unprecedentedly well-funded campaign by the anti-war Liberal Democrats gave prominence to their leader Charles Kennedy as the politician that could be trusted. If 2005 saw comparatively frenetic levels of outdoor advertising, the subsequent economic downturn had an impact on the major parties' ability to mount similarly intensive efforts in the subsequent election 5 five years later. The Conservatives, traditionally the better well-funded campaigner, dominated the more limited 2010 General Election poster battle. The party was even able to hire a second advertising agency, its old partners now known as M\&C Saatchi, to help bolster the efforts of initial appointees Euro RSCG. Euro RSCG's more positive approach had various prospective supporters admitting 'I've never Tory voted before, but'. Personality also informed the Saatchi's decidedly more negative ads andthat featured the smiling face Gordon Brown along with knocking copy such as 'I Doubled the National Debt'. During the most recent General Election of 2015, the same creative team mercilessly honed in on the perceived weakness of Ed Miliband, Brown's successor as Labour leader. In one poster, Miliband was depicted as a 
puppet whose strings were being pulled by Scottish Nationalist Party First Minister Nicola Sturgeon, his party's most likely partner in a coalition government scenario.

7.

\section{Conclusion}

There has been no linear development of the poster from a far-off point where the medium was one distinctive thing that developed - if indeed this is the right term - into its

contemporary form. This is not then a media historical account suggesting a grand sweeping narrative of the kind preferred by some scholars of communication. Such approaches tended to be preoccupied with neologisms, overly associated with recent developments and too generalized (Norris 2000). Arguably, there have beenwere posters produced around 80 years ago where terms such as 'personalization' or 'professionalization' are as applicable to those producedcreated much later in the century (for good discussions of these concepts, see Karvonen 2010; Negrine 2007). But this has been overlooked because the few contemporary chroniclers of these developments have been largely forgotten as well asgiven the tendency to focus on events following the Second World War.

Most previous considerations of poster campaigning have focusedconcentrated on a few memorable examples including, most obviously, the work of Saatchi and Saatchi in the late 1970s onward. This is perhaps understandable given the growing prowess of the advertising industry during the latter stages of the twentieth century of which Saatchis themselves became the ultimate exemplars. Indeed, the agency's political poster work proved invaluable to its own success in serving as the ultimate showcase for the firm's brand. But, as has been demonstrated in this chapter, so much more that happened in this domain before has been comparatively overlookedneglected.

The nature of the political poster has inevitably changed in certain respects from the time when they first became part of the electoral landscape in the nineteenth century. Edwardian and interwar voters experienced outdoor billboard advertisements packed together, sharing promotional billboards. During the century, it became increasingly common for individual posters to occupy their own space, enjoying and commanding a distinctive visual presence. Legal changes had forced restrictions on commercial publicity including the taming of the once manic levels of flyposting that had become a prominent feature of urban environments. Consequently, early 1900s designers' work such as John Hassall's for the Conservatives was predicated on an assumption that his posters had to stand out from an array of other rival promotional material. By contrast, later generations of party publicists, notably Saatchi and Saatchi, enjoyed the luxury of having dedicated space on which to present their advertisements. More arresting outdoor marketing of this kind was increasingly important with the rise of mass transportation either of the public or private kind.

The all-too-fleeting attention prospective voters might give to posters further influenced copywriters to create images and messages that were relatively easy to comprehend. It was a principle embraced by Peter Harle, responsible for designing Labour material during the early post-Second World War era, when he advised: 'Remember always that the basic idea is to present a message in such a way that 'he who runs may read' (Harle 1949).

Attention seeking is a motivation that has informed two significant developments in outdoor election advertising display. Towards the close of the twentieth century, it became increasingly commonplace for rival party leaderships to devise photo-opportunities involving the formal launch of their new poster. Such events have enabled politicians to relay their latest message via press and broadcast media coverage. Consequently, the smaller, less resourced parties have this been able to produce posters for the benefit of news journalists' cameras regardless of whether they had the resources and/or intention to run them as part of a larger, genuine publicity effort. In 2010, even the incumbent governing party, Labour, was 
forced to adopt this method because it lacked sufficient funding to sustain a billboard campaign.

Digital media offer furtheradditional low-cost opportunities for the poster, and the format has arguably been reinvigorated with a series of images that could only be initially viewed online but, like their offline forebears, came to be recycled in mainstream news coverage. Furthermore, this approach had the added advantage of speed and enabled the almost instantaneous rebuttal of opposition claims, particularly those contained in advertisements. In 2010 , for instance, Labour's use of an iconic figure from popular television in one poster to satirize David Cameron was quickly challenged by a rival image that only appeared online but was nevertheless picked up and disseminated alongside the original it sought to undermine (Kavanagh and Cowley 2010, p. 144). This trend looks set to continue. Allied to this outdoor advertising has remained a technique favoured by marketers, notably with technological developments including electronic screens that bring new possibilities. The potential for viral campaigns to shape and influence elections is obvious: the poster, whether static or not, is likely to remain central to this phenomenon.

References

Aulich, J., \& Sylvestrova, M. (1999). Political posters in central and eastern Europe 19451995. Manchester: Manchester University Press.

Ball, S. (2012). Dole queues and demons: British election posters from the conservative party Archive. Oxford: Bodleian Library.

Barnicoat, J. (1972). Posters. London: Thames \& Hudson.

Beers, L. (2010). Your Britain: Media and the making of the labour party. Harvard: Harvard University Press.

Bell, T. (1982). The conservatives' advertising campaign. In R. Worcester \& M. Harrop (Eds.), Political communications: The general election campaign of 1979. London: Allen and Unwin.

Bonnell, V. (1999). Iconography of power: Soviet political posters under Lenin and Stalin. Berkley: University of California Press.

Burgess, A. E. (1921). Pictorial propaganda. Labour Organiser, 7, 16.

Burgess, C. (2011). "This election will be won by people not posters"... advertising and the 2010 general election'. In D. Wring, R. Mortimore, \& S. Atkinson (Eds.), Political communication in Britain. London: Palgrave Macmillan.

Burgess, C. (2014). From the political pipe to the devil eyes: A history of the British Election Poster from 1910-1997, Unpublished PhD dissertation, University of Nottingham.

Butler, D., \& Kavanagh, D. (1980). The British general election of 1979. Hampshire: Macmillan.

Butler, D., \& Rose, R. (1960). The British general election of 1959. London: Macmillan. Caldwell, B. (1980, February 19). So much for Tory election promises. Daily Star. Cambray, P. (1932). The game of politics: A study of the principles of British political strategy. London: John Murray.

Campbell, L. (1999, October 15). Tories ‘Labour isn’t Working' judged the Century's top poster. Campaign.

Central Office. (1911). Unionist Organisation Committee Report, June. Conservative Central Office. Reference CCO 500/1/2.

Cockett, R. (1994). Party publicity and the media. In A. Seldon \& S. Ball (Eds.), The conservative century since 1900. Oxford: Oxford University Press.

Committee on Advertising Practice. (2014). The CAP code: The UK code of non-broadcast advertising, sales promotion and direct marketing (12th ed.). London: Committee on Advertising Practice. 
Crewe, I. (1981). Why the conservatives won. In H. Penniman (Ed.), Britain at the polls 1979: A study of the general election. Washington: American Enterprise Institute.

Decaux, J. C. (2010, August 31). Large format production guide.

http://www.jcdecaux.co.uk/products/billboards/ .

Dumitrescu, D. (2012). The importance of being present: Election posters as signals of electoral strength, evidence from France and Belgium. Party Politics, 18, 6.

Fisher, J. (2015, September). Party finance: The death of the national campaign?

Parliamentary Affairs, 68, 133-153.

Gallo, M. (1974). Posters in history. New York: American Heritage.

Gorman, J. (1985). Images of labour. London: Scorpion.

Gorman, J. (1996). The labour party's election posters in 1945. Labour History Review, 61(Winter), 299-308.

Harle, P. (1949). Designing a poster. Labour Organiser, 28, 12-13.

Hassall, J. (1911). Posters. In T. Russell (Ed.), Advertising and publicity. London:

Educational Book.

Horrie, C. (2001). "Epoch-making Poster" was a clever fake.

http://news.bbc.co.uk/1/hi/uk/1222326.stm .

Hutchison, H. (1968). The poster. London: Studio Vista.

James, P. (2009). Introduction: Reading world war I posters. In P. James (Ed.), Picture this:

World war I posters and visual culture. Nebraska: University of Nebraska Press.

Jowett, G., \& O’Donnell, V. (1992). Propaganda and persuasion. London: Sage.

Karvonen, L. (2010). The personalisation of politics. Colchester: ECPR Press.

Kavanagh, D., \& Cowley, P. (2010). The British general election of 2010. Hampshire:

Palgrave Macmillan.

Lawrence, J. (2009). Electing our masters: The Hustings in British politics from Hogarth to

Blair. Oxford: Oxford University Press.

Lazarsfeld, B., Berelson, B., \& Gaudet, H. (1944). The people's choice. New York: Duell,

Sloan \& Pearce.

Negrine, R. (2007). The professionalisation of political communication in Europe. In R.

Negrine, P. Mancini, C. Holtz-Bacha, \& S. Papathanassopoulos (Eds.), The

professionalisation of political communication: Changing media, changing Europe. Bristol:

Intellect.

Norris, P. (1997). Electoral change in Britain since 1945. Oxford: Oxford University Press. Norris, P. (2000). A virtuous circle: Political communication in post-industrial societies. New York: Cambridge University Press.

Pall Mall Gazette. (1910, February). The poster election. Pall Mall Gazette, 211.

Pinto-Duschinsky, M. (1981) British campaign finance 1830-1980. Washington: American Enterprise Institute.

Rickards, M. (1970). Posters of protest and revolution. Somerset: Adams \& Dart.

Rowland, C. (1960). Labour publicity. Political Quarterly, 31, 3.

Scammell, M. (1995). Designer politics. Hampshire: Macmillan.

SCAN. (2012). Capitalism isn't working (banner).

www.swindonclimate.org.uk/20081206London.

Seidman, S. (2008). Posters, propaganda and persuasion. New York: Peter Lang.

Thompson, J. (2007). "Pictorial lies?" posters and politics in Britain, 1880-1914. Past and

Present, 197, 177-210.

Trent, J. S., \& Friedenberg, R. V. (2007). Political campaign communications: Principles and practices (6th ed.). New York: Rowman \& Littlefield.

Wallas, G. (1948). Human nature in politics. London: Constable. First published 1908. 
Weill, A. (1985). The poster: A worldwide history and survey. Boston: GK Hall. Wilson, H. (1986) Memoirs: the making of a Prime Minister 1916-64. London: Weidenfeld and Nicolson/Michael Joseph.

Wring, D. (2005). The politics of marketing the labour party. Hampshire: Palgrave Macmillan. 